\title{
Effect of Agronomic Practices on Green Fodder, Grain Quality, Grain Yield and Economics of Dual Purpose Barley (Hordeum vulgare L.)
}

\author{
Gurpreet Kaur Gill*, C.S. Aulakh and P.K. Sharma \\ Department of Agronomy, Punjab Agricultural University, Ludhiana - 141004, India \\ *Corresponding author
}

\section{A B S T R A C T}

\begin{tabular}{|l|}
\hline Ke y w o r d s \\
$\begin{array}{l}\text { Forage yield, } \\
\text { Grain yield, Time } \\
\text { of cutting and dual } \\
\text { purpose barley }\end{array}$ \\
\hline Article Info \\
\hline $\begin{array}{l}\text { Accepted: } \\
\text { 19 June } 2017 \\
\text { Available Online: } \\
\text { 10 July } 2017\end{array}$ \\
\hline
\end{tabular}

A field experiment was conducted during the winter (Rabi) season at Punjab Agricultural University, Ludhiana for two years to study the effect of time of cutting for forage on grain quality, grain yield, green fodder yield and economics of dual purpose barley varieties. The treatments, comprising the uncut, one green foliage cut (45 and 60 days after sowing), were evaluated against three varieties (PL 172, PL 426 and RD 2552). Barley variety PL 172 produced significantly higher green fodder yield $\left(10.5 \mathrm{t} \mathrm{ha}^{-1}\right)$ than the other two varieties i.e. PL 426 and RD 2552. The varieties RD 2552 (3.9 $\left.\mathrm{t} \mathrm{ha}^{-1}\right)$ and PL $172\left(4.2 \mathrm{t} \mathrm{ha}^{-1}\right)$ were statistically at par but gave significantly higher grain yield than PL $426\left(3.6 \mathrm{t} \mathrm{ha}^{-1}\right)$. The variety RD 2552 gave higher net returns of Rs $41660 \mathrm{ha}^{-1}$ than other two varieties i.e. PL 172 (Rs $27229 \mathrm{ha}^{-1}$ ) and PL 426 (Rs $22194 \mathrm{ha}^{-1}$ ). The forage cut at 60 days after sowing (DAS), produced significantly higher green fodder $\left(13.4 \mathrm{t} \mathrm{ha}^{-1}\right)$ than the forage cut at 45 DAS. The uncut crop and cut crop at 45 DAS produced significantly higher grain yield (4.6 and $4.5 \mathrm{tha}^{-1}$ ) yield than the cut crop at $60 \mathrm{DAS}$. The cutting of barley for fodder at 45 DAS gave higher net returns (Rs $24284 \mathrm{ha}^{-1}$ ) than the forage cut at 60 DAS and uncut crop.

\section{Introduction}

During pre-green revolution, barley is the major staple cereal. By virtue of hardy and versatile nature, superior nutritional value (soluble digestible fibers, low gluten, palatable and succulent leaves), satisfactory better grain yield and medicinal importance (due to presence of beta glucon, acetylcholine, desirable chlorophyll and antioxidant), barley is supposed to be crop of present era.

World community and farm scientists have also started thinking about the crops that have high productivity for feed and fodder with lesser amount of inputs, particularly, water and fertilizers and may be grown on marginal lands. To overcome this situation, dualpurpose crop production systems are required. Barley is the crop which has the potential for fodder-cum-grain production. A successful dual-purpose crop should provide a substantial amount of forage and regenerate so that a good yield of grain could be harvested. Yau and Mekni (1985) classified dual purpose barley cultivars as having high forage yield at grazing time and high grain yield after grazing.

Since animal component is essential linked with farming to sustainability of the marginal 
and poor farmers, barley also provides green as well as dry fodder to this section of farming community. In the recent years, it has been observed that because of severe drought in the drier parts of northern plains (Rajasthan, Southern Haryana, South-west Punjab and Western U.P.) there has an acute shortage of green fodder in the months of November to January. Barley and oats possesses good regeneration capacity after taking first cutting as fodder. This characteristic of barley can be exploited to use it as fodder during lean periods of DecemberJanuary by taking one cutting during the active vegetative growth stage and then leaving the regenerated crop for grain production particularly around urban areas. The crop can be advantageous over oats, because of its dual utilization as well as lesser water requirements.

Keeping above facts in view the present investigation was planned to sort out better dual purpose barley varieties for filling the wider gap between demand and supply of green forage in the country and for taking grain yield from the regenerated crop.

\section{Materials and Methods}

A field experiment was carried out during Rabi 2006-07 and 2007-08 at Students' Research farm in the department of Agronomy, Punjab Agricultural University, Ludhiana $\left(30^{\circ} 55^{\prime} \mathrm{N}\right.$ and $75^{\circ} 54^{\prime} \mathrm{E}$ and 247 meter above the mean sea level), Punjab. Nine treatment combinations comprising three varieties (PL 172, PL 426 and RD 2552) and three green forage cut treatments (cutting at 45 and 60 days after sowing), were evaluated. The experiment was laid out in factorial split plot design with three replications, assigning varieties in main plots and cutting management in sub-plots. The soil was loamy sand in texture, normal in reaction $(\mathrm{pH} 7.5)$, low in available nitrogen (201 kg ha $\left.{ }^{-1}\right)$ and medium in available phosphorous (19.7 $\mathrm{kg}$ $\mathrm{ha}^{-1}$ ) and available potassium (218 $\left.\mathrm{kg} \mathrm{ha}^{-1}\right)$. The crop was sown with a uniform seed rate of $90 \mathrm{~kg} \mathrm{ha}^{-1}$ during first week of November and a basal dose of $62.5 \mathrm{~kg} \mathrm{~N}, 30 \mathrm{~kg} \mathrm{P}_{2} \mathrm{O}_{5}$ and $15 \mathrm{~kg} \mathrm{~K}_{2} \mathrm{O} \mathrm{ha}^{-1}$ was applied. The required amount of $\mathrm{N}, \mathrm{P}$ and $\mathrm{K}$ nutrients was supplied through urea, diammonium phosphate and muriate of potash, respectively. The crop for green fodder was cut with the help of sickle at a height of 5 $\mathrm{cm}$ from the ground level after 45 and 60 days after sowing as per treatments and green fodder yield was recorded. After green foliage cut crop was irrigated and an additional 25 percent $\mathrm{N}$ was applied in the plots where one cutting for forage was taken. A $100 \mathrm{~g}$ green fodder sample was kept in hot air oven $\left(70 \pm 1{ }^{0} \mathrm{C}\right.$ for $\left.72 \mathrm{hrs}\right)$ for recording dry matter yield. Economics was computed based on selling price of green fodder Rs $90 \mathrm{q}^{-1}$, while barley grain and straw produce Rs $650 \mathrm{q}^{-1}$ and Rs $100 \mathrm{q}^{-1}$, respectively during both the years. Cost of truthfully labeled seeds of barley varieties was Rs/q. cost of manual labour was Rs 18 man-hour $^{-1}$. Other package of practices recommended for the state was followed. The data were statistically analyzed.

\section{Results and Discussion}

\section{Effect of varieties}

RD 2552 and PL 172, statistically on par with each other, took significantly more number of days (104.8 and 104.4 days, respectively) for heading than PL 426 (100.7 days). Varieties did not differ significantly in number of days taken for maturity (Table 1). The varieties PL 426 and PL 172, statistically on par with each other, produced significantly taller plants than RD 2552. The varieties RD 2552 and PL 172 produced significantly higher number of effective tillers per unit area and 1000 grain weight than PL 426. The variety PL 172 had 
significantly longer ear and higher number of grains per ear than PL 172 and RD 2552. The varieties RD $2552\left(4.8 \mathrm{t} \mathrm{ha}^{-1}\right)$ and PL 172 (4.2 $\mathrm{t} \mathrm{ha} \mathrm{h}^{-1}$ ) were statistically at par, produced significantly higher grain yield than PL 426 (3.6 $\mathrm{t} \mathrm{ha}^{-1}$ ). Higher grain yield of RD 2552 variety might be due to higher number of effective tillers $\mathrm{m}^{-2}$, and 1000-grain weight. The variety RD 2552 yielded significantly higher straw yield (6.1 t ha $\left.{ }^{-1}\right)$ than PL 172 and PL 426, the variety also had higher harvest index than the latter two varieties. Significantly more hectoliter weight was exhibited by PL 172 variety than RD 2552 which was at par with PL 426 variety of barley. The grain quality parameters such as protein, starch and kernel plumpness did not differ significantly with respect to varieties. Variety PL 172 produced significantly higher green fodder yield and dry matter yield (10.5 and $1.8 \mathrm{t} \mathrm{ha}^{-1}$, respectively) than the other two varieties of barley i.e. PL 426 and RD 2552 which were statistically at par with each other (Table 3). The barley variety RD 2552 recorded more gross as well as net returns than that of varieties PL 172 and PL 426. Higher net returns of Rs $41660 \mathrm{ha}^{-1}$ were recorded under variety RD 2552, which were 53.0 and 87.7 per cent higher than varieties PL 172 and PL 426, respectively, was mainly attributed to more grain and straw yields. RD variety registered more benefit by Rs 0.96/rupee and Rs 1.30 rupee $^{-1}$ invested (benefit: cost ratio 2.78) over varieties PL 172 and PL 426, respectively.

\section{Cutting management}

Cut crop recorded delayed heading compared to uncut crop. Among the forage cutting treatments, forage cut at 45 DAS attained heading significantly earlier than forage cut at 60 DAS. There was a delay of 6.8 days in attaining the heading stage in early cutting at 45 DAS than the uncut crop. There was a further delay of 15 days in attaining heading stage with delay of 15 days for forage harvest.
The dual purpose lines tended to be later in heading than the grain types (Hadjichristodoulou, 1983; Yau et al., 1987). The uncut crop also recorded significantly early maturity than cut crop. The forage cut at 60 DAS took significantly more number of days to maturity than forage cut at 45 DAS. There was delay of 2 and 5 days when forage cut at 45 DAS and 60 DAS was taken, respectively than the uncut crop. The time to maturity appeared to be the main factor affecting yields (Hadjichristodoulou, 1983; Yau et al., 1987). Maturity was delayed by forage harvest but not to the same degree as heading (Poysa, 1985).

Plant height of barley was significantly higher when crop was raised only for grain purpose than the crop which was raised for dual purpose. Among dual purpose treatments plant height further reduced significantly with further delay in forage harvest (Table 2). Forage harvest of barley might have slowed down the rate of internode elongation and caused reduction in the supply of assimilates from the leaves to roots. This might be the reason for shorter plants with forage removal. Kumar et al., (1999) also recorded significantly higher plant height of wheat when the crop was raised with no cut as compared to the crop where one cut was imposed for taking additional forage yield. The number of effective tillers (546.4) was produced significantly higher in uncut crop but it was at par with treatment where one cutting for forage was taken at 45 DAS. Further delay in forage harvest to 60 DAS significantly reduced the number of effective tillers per unit area. Reduction in effective tillers might be due to forage removal as forage harvest imposed the stress on roots due to lesser photosynthetic assimilation and resulted in decreased dry matter accumulation and further turn out of tillers to effective tillers. Khair et al., (2003) also reported similar results. 
Table.1 Effect of agronomic practices on yield attributes of dual purpose barley

(Pooled data of 2006-07 and 2007-08)

\begin{tabular}{|l|c|c|c|c|c|c|c|}
\hline Treatments & $\begin{array}{c}\text { Days to } \\
50 \% \\
\text { heading }\end{array}$ & $\begin{array}{c}\text { Days to } \\
50 \% \\
\text { maturity }\end{array}$ & $\begin{array}{c}\text { Plant } \\
\text { height } \\
(\mathrm{cm})\end{array}$ & $\begin{array}{c}\text { Effective } \\
\text { tillers } \\
\mathrm{m}^{-2}\end{array}$ & $\begin{array}{c}\text { Ear } \\
\text { length } \\
(\mathrm{cm})\end{array}$ & Grains ear $^{-1}$ & $\begin{array}{c}1000 \text { grain } \\
\text { weight }(\mathrm{g})\end{array}$ \\
\hline Varieties & 104.4 & 151.8 & 96.7 & 522.8 & 7.2 & 57.9 & 41.5 \\
\hline PL 172 & 100.7 & 150.9 & 96.8 & 479.7 & 7.9 & 62.4 & 37.9 \\
\hline PL 426 & 104.8 & 152.5 & 87.9 & 548.7 & 6.4 & 55.3 & 42.1 \\
\hline RD 2552 & 1.3 & $\mathrm{NS}$ & 6.5 & 35.5 & 0.3 & 3.4 & 2.8 \\
\hline CD $(P=0.05)$ & \multicolumn{7}{|l|}{} \\
\hline Time of cutting for forage \\
\hline No cut & 94.0 & 149.5 & 99.2 & 546.4 & 7.6 & 62.4 & 43.3 \\
\hline One cut at 45 DAS & 100.8 & 151.5 & 93.9 & 534.3 & 7.2 & 59.7 & 40.7 \\
\hline One cut at 60 DAS & 115.1 & 154.3 & 88.1 & 470.0 & 6.6 & 53.4 & 34.6 \\
\hline CD $(P=0.05)$ & 1.6 & $\mathbf{1 . 3}$ & 4.1 & 25.6 & 2.0 & 2.0 & 2.7 \\
\hline
\end{tabular}

Table.2 Effect of agronomic practices on grain yield and quality of dual purpose barley (Pooled data of 2006-07 and 2007-08)

\begin{tabular}{|l|c|c|c|c|c|c|c|}
\hline Treatments & $\begin{array}{c}\text { Grain } \\
\text { yield } \\
\left(\mathrm{t} \mathrm{ha}^{-1}\right)\end{array}$ & $\begin{array}{c}\text { Straw } \\
\text { yield } \\
\left(\mathrm{t} \mathrm{ha}^{-1}\right)\end{array}$ & $\begin{array}{c}\text { Harvest } \\
\text { index }\end{array}$ & $\begin{array}{c}\text { Hectoliter } \\
\text { weight } \\
\left(\mathrm{kg}^{-1} \mathrm{hl}\right)\end{array}$ & $\begin{array}{c}\text { Protein } \\
(\%)\end{array}$ & $\begin{array}{c}\text { Starch } \\
(\%)\end{array}$ & $\begin{array}{c}\text { Kernel Plumpness } \\
(\text { Weight basis \%) } \\
(>\mathbf{2 . 5 m m})\end{array}$ \\
\hline Varieties & 4.15 & 5.73 & 0.42 & 59.9 & 10.1 & 62.9 & 76.0 \\
\hline PL 172 & 3.61 & 5.24 & 0.41 & 58.6 & 9.5 & 62.4 & 69.4 \\
\hline PL 426 & 4.78 & 6.11 & 0.44 & 57.0 & 10.1 & 62.3 & 78.1 \\
\hline RD 2552 & 0.64 & 0.36 & - & 2.2 & NS & NS & NS \\
\hline CD $(P=0.05)$ & \multicolumn{7}{|l|}{} \\
\hline Time of cutting for forage \\
\hline No cut & 4.56 & 6.31 & 0.42 & 60.2 & 10.1 & 62.4 & 88.0 \\
\hline One cut at 45 DAS & 4.50 & 5.69 & 0.44 & 59.1 & 10.1 & 62.2 & 78.0 \\
\hline One cut at 60 DAS & 3.49 & 4.74 & 0.42 & 56.1 & 9.4 & 63.0 & 57.6 \\
\hline CD $(P=0.05)$ & 0.33 & 0.63 & - & 1.6 & 0.5 & 0.4 & 5.6 \\
\hline
\end{tabular}

Table.3 Effect of agronomic practices on fodder yield and economics of dual purpose barley (Pooled data of 2006-07 and 2007-08)

\begin{tabular}{|c|c|c|c|c|c|c|}
\hline Treatments & $\begin{array}{c}\text { Green fodder } \\
\text { yield } \\
\left(\mathrm{t} \mathrm{ha}^{-1}\right)\end{array}$ & $\begin{array}{l}\text { Cut dry matter } \\
\text { yield } \\
\left(\mathrm{t} \mathrm{ha}^{-1}\right)\end{array}$ & $\begin{array}{l}\text { Cost of } \\
\text { cultivation } \\
\left(\mathrm{Rs} \mathrm{ha}^{-1}\right)\end{array}$ & $\begin{array}{l}\text { Gross } \\
\text { returns } \\
\left(\mathrm{Rs} \mathrm{ha}^{-1}\right)\end{array}$ & $\begin{array}{c}\text { Net returns } \\
(\mathrm{Rs} \\
\left.\mathrm{ha}^{-1}\right)\end{array}$ & $\begin{array}{l}\text { Benefit: } \\
\text { Cost ratio }\end{array}$ \\
\hline \multicolumn{7}{|l|}{ Varieties } \\
\hline PL 172 & 10.54 & 1.79 & 14962 & 42191 & 27229 & 1.82 \\
\hline PL 426 & 9.39 & 1.56 & 14962 & 37156 & 22194 & 1.48 \\
\hline RD 2552 & 9.78 & 1.59 & 14962 & 56622 & 41660 & 2.78 \\
\hline $\mathrm{CD}(P=0.05)$ & 0.47 & 0.11 & - & - & - & - \\
\hline \multicolumn{7}{|c|}{ Time of cutting for forage } \\
\hline No cut & - & - & 14962 & 35950 & 20988 & 1.40 \\
\hline One cut at 45 DAS & 6.44 & 0.96 & 16452 & 40736 & 24284 & 1.48 \\
\hline One cut at 60 DAS & 13.37 & 2.34 & 17202 & 39458 & 22256 & 1.29 \\
\hline $\mathrm{CD}(P=0.05)$ & 0.49 & 0.12 & - & - & - & - \\
\hline
\end{tabular}


Ear length and number of grains per ear were significantly higher in grain purpose treatment than dual purpose treatments. Significantly more 1000-grain weight was obtained in uncut crop than the forage cut at 60 DAS but at par with forage cut at 60 DAS. Dual purpose treatments also differed significantly in their 1000-grain weight and there was a significant reduction in it with delay in forage cutting. The reduced 1000-grain weight with forage cut might be due to more percentage of shriveled grains with forage cutting due to shortening of grain filling period and the percentage of shriveled grains further increased with delay in forage harvest. Sharma et al., (2001) also reported that forage cutting at 65 DAS produced higher 1000grain weight than forage cutting at 80 DAS. El-Shatnawi and Haddad, (2004) also reported similar results.

Significant differences in grain yield and straw yields were observed due to cutting management. The uncut crop and forage cut at 45 DAS were statistically at par but produced significantly higher grain yield and straw yields than forage cut at 60 DAS (Table 2 ). There was significant reduction in grain yield and straw yields with further delay of forage harvest. With delay in forage harvest, grain yield and straw yields reduction might be due to shortening of vegetative and reproductive period. Shortening of grain filling period might have led to forced maturity thereby production of more shriveled grains and significant reduction in 1000-grain weight and ear characteristics. Yau (2003) also reported similar results in barley. The yield components, reduced by clipping, were the most important contributors to loss of grain yield (EI-Shatnawi and Haddad, 2004). The grain quality parameters viz. hectoliter weight, protein and starch content was recorded significantly higher in uncut crop and forage cut at 60 DAS. Kernel plumpness was recorded significantly higher in uncut crop than the cutting treatments. There was further significant reduction in all the grain quality parameters with further delay in forage harvest. Data revealed that the forage cut at $60 \mathrm{DAS}$, produced significantly higher green fodder yield (13.4 t/ha) and cut dry matter yield $(2.3 \mathrm{t} / \mathrm{ha})$ than the forage cut at 45 DAS (Table 3). Midha et al., (1999) also reported maximum green herbage yield with cutting at 80 DAS than cutting at 50 DAS due to higher dry matter accumulation and increased plant height.

Gross and net returns showed a variation among the cutting treatments (Table 3 ). The forage cut at 45 DAS recorded higher gross returns than the forage cut at 60 DAS and uncut crop. The higher gross returns (Rs $40736 \mathrm{ha}^{-1}$ ), net returns (Rs $24284 \mathrm{ha}^{-1}$ ) and benefit: cost ratio (1.48) was recorded from the crop where forage was at 45 DAS over the forage cut at 60 DAS and uncut crop. The uncut crop registered more benefit by Rs 0.11 rupee $^{-1}$ invested over the forage cut at 60 DAS.

In conclusion, the variety PL 172 of barley is best suited for dual purpose production. Dual purpose barley should be grown at a row spacing of $15 \mathrm{~cm}$ to get higher fodder production. One forage cut of dual purpose barley may be taken at 45 days after sowing (DAS) without any yield reduction and it can be delayed upto 60 DAS to get almost double production of green fodder than that at 45 DAS but at the cost of 25 percent reduction in grain yield.

\section{References}

EI Shatnawi, M. K. J., and Haddad. N. I. 2004. Assessing barley (Hordeum vulgare) response to clipping in the semi-arid Mediterranean Climate. Australian Journal of Experimental Agriculture. 44(1): 34-42. 
Hadjichristodoulou, A. 1983. Dual purpose barley. Agricultural Research Institute Ministry of Agric and Natural Resources, Nicosia, Cyprus, Technical Bulletin. 46: pp 9.

Khair, J. M., Shatnami E I., Louy, Z., Qurran, A. L., and Ereifej, K. I. 2003. Seasonal growth and chemical composition of dual-purpose barley. Crop Research. 25(1): 28-36.

Kumar, S., Badiyala, D., Singh, C. M., and Saroch, K. 1999. Nitrogen and cutting management in winter wheat (Triticum aestivum) under dry temperate high hills. Indian Journal of Agronomy. 44(1): 112-14.

Midha, L. K., Panwar, K. S., and Sharma, S. K., 1999. Effect of cutting frequency and time of nitrogen application on yield and quality of oats (Avena sativa L). Forage Research. 25(2): 99-102.

Poysa, V. N. 1985. Effect of forage harvest on grain yield and agronomic performance of winter triticale, wheat and rye. Canadian Journal of Plant Sciences. 65: 879-888.

Sharma, S. K., Bhunia, S. R., and Yadava, D. K. 2001. Response of oat (Avena sativa L) to cutting management, method of sowing and nitrogen. Forage Research. 27(3): 167-70.

Yau, S. K., and Mekni, M. S., 1985. Characterization of dual purpose barley - an approach. Rachis. 4(1): 33-34.

Yau, S. K., Mekni, M. S., Naji, I., and Srivastava, J. P., 1987. Effects of greenstage grazing on rainfed barley in northern Syria. Yields and economic returns. International Centre for Agricultural Research in the Dry Areas. Allepo, Syria (Report).

Yau, Sui-Kwong. 2003. Yield of early planted barley after clipping or grazing in a semiarid area. Agronomy Journal. 95(5): 821-27.

\section{How to cite this article:}

Gurpreet Kaur Gill, C.S. Aulakh and Sharma, P.K. 2017. Effect of Agronomic Practices on Green Fodder, Grain Quality, Grain Yield and Economics of Dual Purpose Barley (Hordeum vulgare L.). Int.J.Curr.Microbiol.App.Sci. 6(7): 1492-1497. doi: https://doi.org/10.20546/ijcmas.2017.607.178 